\title{
A MARKETING STRATEGY FOR A NURSING COLLEGE
}

\author{
M Pryde and M Muller
}

\begin{abstract}
The objective of this study is to explore and describe a marketing strategy for a nursing college. An explorative and descriptive research design, within the context of a nursing college and affiliated hospitals, was followed. A literature study of marketing modets was undertaken and the Delphi-method was utilised to determine the contribution of marketing staff and the possibte content of a marketing strategy for a nursing college. The results were utilised to describe guidelines for such a strategy, consisting of marketersimarketing agents, target market, product, price. promotional activities, place and market research Recommendations include the planning, implementation and evaluation of strategy, inservice training for potential marketing agents, inclusion of marketing as part of the formal education of tutors and nurse managers, as well as an impact study of the scholar as the main cansumer.
\end{abstract}

\section{UITTREKSEL}

Hierdie studie spreek die bemarkingsprobleem van ' $n$ verplegingskollege aan, met die doel om' $n$ bemarkingstrategie vir ' $n$ verplegingskollege te verken en te beskryf. ' $n$ Verkennende en beskrywende navorsingsontwerp is nagevolg. binne die konteks van 'n yerplegingskollege en geraffitieerde hospitale. 'n Literatuurstudie van bematkingsmodelle is onderneem, asook die benutting van die Delphi-metode om die bydrae van bemarkers, asaok die moontlike inhoud van 'n bemarkingstrategie vir ' $n$ verplegingskollege te bepal. Die resultate is gebruik om riglyne vir' $n$ bemarkingstrategie vir $n$ verplegingskollege te beskryf, bestaande uit die bemarkers, teikengroep, produk, prys, promosie, plek en marknavorsing. Aanbevelings sluit in die beplanning, implementering en evaluering van 'n bemarkingstrategie, indiensopleiding aan potensiële bemarkers, asook die insluiting van bemarking as deel van die formele opleiding van dosente en verpleegdiensbestuurders. ' $n$ Impakontleding van die skolier as vernaamste verbruiker, word ook aanbeveet.

\section{INTRODUCTION}

Research has proven a shortage of nurses in the country. In 1991 the ratio of registered nurses to the population was 1:435 (Muller, 1991). To attain the ideal ratio of registered nurses to the population in South Africa, nursing education institutions are compelled to introduce marketing strategies. This statement is qualified by the fact that $71 \%$ student nurses agreed that current recruitment programmes do not create realistic role expectations (Esterhuizen, 1989). As first year students are highly motivated and enthusiastic on entering the profession (Woolf, 1987:46), but dissatisfied toward the end of their training, it is evident that existing marketing strategies need to be examined.

As most health care institutions have been concentrating on promotional activities only, it has become clear that the concept of developing a marketing strategy needs to be explored. A marketing strategy is a structured plan which guides the organisation's activities to reach set goals (Massie, 1979:209). Strategic planning forms an integral part of the management function of a nursing college, so the development of a marketing strategy should feature (Schulz \& Johnson, 1990:77). De Jager (1990) describes promotion as the physical promoting of a product by communicating the possible uses of trial tests to the consumer. Recruitment forms part of this element of a marketing strategy and nursing colleges indeed have been practising one element of marketing, but not all of them Elements such as producer, market, place, price. product or market research have not formed part of the plan. Recruitment is thus seen as one of the goals of a marketing strategy. Baird (1991) supports this opinion, adding that an institution can ensure growth through a marketing programme.
An active marketing programme contributes to the awareness of all nurses to their role in the marketing of nursing as a profession and of nursing education in particular. Nursing colleges nevertheless do not use formal marketing strategies and the persons responsible for marketing strategies do not have guidelines within which to operate, therefore the following questions arise:

- of what should the content of a nursing college marketing strategy consist?

- how could the educational or affiliated staff of the nursing college contribute towards the marketing function of the college?

The aim of this study is to explore and describe a marketing strategy for a specific nursing college in Transvaal (now Gauteng)

\section{TERMINOLOGY}

\section{Marketing}

Marketing is a total system of interactional activities in an organisation designed to plan, price, promote and distribute need satisfying products to existing and potential consumers (Stanton, 1975:5). In this study marketing refers to the activities in a nursing college to design, price, promote and distribute information regarding a quality nursing course to existing potential consumers.

\section{Marketing strategy}

A marketing strategy is a structured programme or plan which guides the organisation's marketing activities regarding format, actions and timing, with reference to the product, price, place, promotion and market research (Massie, 1979:209). The marketing strategy also specifies the contributions of potential marketers, as well as the content of the marketing education programme.

\section{Marketer}

The marketer is the person involved with any marketing activity. In this study the marketer refers to the educational staff of a nursing college, as well as nursing staff working in any hospital affiliated to the nursing college.

\section{Nurse}

The nurse is a person who is registered with 
the South African Nursing Council as a professional nurse and on the staff of one of the six hospitals affiliated to the nursing college under study.

\section{Nursing student}

The nursing student is a person registered with the South African Nursing Council for the course leading to registration in Nursing (General, Psychiatric and Community Health) and Midwife.

\section{RESEARCH METHODOLOGY}

A descriptive exploratory design was followed, within the context of a nursing college and the affiliated hospitals, situated in Transvaal. The research was conducted in three phases:- a literature study to analyse existing marketing models for service professions as the conceptual framework, the Delphi technique in two rounds, and verification of results by means of interviews. The final marketing strategy was verified by a marketing consultant during an interview.

The initial marketing strategy or conceptual framework was described, based on the literature study, mainly using the marketing models of Fine (1990) and Strasen (1987). The following main themes were identified and consequently utilised for categorising the first Delphi round results:

- producer or marketer of the product (nursing college);

- consumer in the market (potential nursing students);

- product (nursing education programme and quality nursing care by well educated professional nurses);

- price to sacrifice for the product (monetary and social sacrifices made);

- promotion or consultation with the market (career selling);

- place and availability of product (nursing college and clinical facilities);

- market research required to implement and evaluate the marketing strategy.

The Delphi method is a research technique whereby the opinion of a group of knowledgeable persons about a specific subject is collected through questionnaires. Group consensus is achieved without face to face confrontation (Lindeman, 1975). During the first round of the Delphi technique, biographical information was collected to determine the marketing status of the potential marketers.

In this first round the content of the nursing college's marketing strategy was investigated, as well as the possible contributions of the marketers. A content analysis was performed, using the main categories of the conceptual framework derived from the literature study, to categorise the results. The results of round one were prepared in the form of a structured questionnaire. These were presented in round two of Delphi to a representative panel of potential marketers, derived from the population sample in round one, as well as to an experienced marketing consultant for final verification purposes. In this final Delphi round, the participants were also expected to indicate the potential impact of each marketing activity based on their own opinion and practice reality. Finally guidelines for a marketing strategy for the nursing college were described, based on these results.

The population for this study included all potential marketers in the nursing college, as well as the affiliated hospitals. Inclusion criteria were formulated after consultation with the marketing consultant and potential marketers. These criteria were the following:

- appointment in a post of senior or chief professional nurse, or nursing service manager, in the nursing college and/or affiliated hospitals;

- informed commitment and consent to participate in the research;

- a positive attitude towards marketing activities verbalised by potential participants;

- availability to participate during the research period.

Twenty participants in the nursing college, and twelve participants in each of the six affiliated hospitals, were identified in consultation with the statistical consultant and nursing service managers of the hospitals. A field worker/mediator in each of the institutions (six hospitals and nursing college) assisted the researcher in the distribution and collection of the questionnaires in both rounds, ensuring ethical control during the research. The statistical consultant confirmed the sample as representative of the target population.

Selected reliability and validity measures were employed during the research. The content validity of the funal marketing strategy was confirmed by the literature study and results of the Delphi rounds. The marketing consultant also verified the final marketing strategy for the nursing college. An independent researcher was utilised during the content analysis of the Delphi results and an inter-rater reliability of almost $99 \%$ was confirmed. Operational reliability and validity was ensured by following the steps of the chosen research methodology meticulously. Reliability of results also was controlled in that panel members gave their opinions in a goal directed manner, writing their responses without being influenced by other panel members. A controlled situation in each research setting was ensured by the mediators, following the research instructions. The results of the questions were subjected to inductive processing to confirm objectivity (Lindeman, 1975). During the second Delphi round the questions were separated for value and impact rating. Results of the second phase were processed in a rigid scientific manner and verified by the marketing panel members and an experienced marketing consultant.

\section{RESULTS}

The results are described in three phases. In the first phase the first Delphi round results are given. The second phase deals with the second Delphi round results, followed by the final phase of describing the marketing strategy for the nursing college.

Phase one: Marketing within the context of nursing

During the first Delphi round panel members were asked to explain the concept of marketing, what it meant in the nursing profession, what and how they could contribute as marketers, and which subjects they could suggest for inclusion in a marketing programme / strategy for the nursing college A total of 92 questionnaires were distributed to the identified panel members and 77 $(83,6 \%)$ responded, varying between $75-100 \%$ sample realisation in the different research units.

The responses were categorised according to the main themes of the conceptual framework for marketing, ie producer, consumer, product, price, promotion, place and market research Marketing was seen by the panel members as recruitment of potential nursing students, advertising the nursing profession by means of both direct and indirect methods. Direct methods could include a well planned and organised marketing programme by the nursing college and indirect methods relate mostly to the portraying of a positive image by all nurses.

According to the panel members the nursing college, hospitals, educational and hospital staff, as well as the students, all could be potential marketers. The marketer is seen as the producer and presenter (Fine, 1990:4) of the nursing course. It is clear that the panel members view marketing as a promotion element and the need for a structured educational programme for marketing is confirmed.

Potential consumers were identified as community and church leaders, scholars, parents, the general public, the media, career counsillors and teachers. The results of this category show that panel members include all potential consumers as the target population, which can be very expensive - a more focused target group is required.

The product was identified as the whole nursing course, advantages and disadvantages of a nursing career, professionalism, an appropriate curriculum to meet the health 
needs of the population served, job satisfaction, personal and professional growth, payment while studying, acquisition of interpersonal and life skills, valuable education, service benefits, opportunities for promotion and realistic information about nursing, and above all - quality nursing care delivered by the nurses who have completed their studies at this particular nursing college.

The price of the product could be related to the value for the consumer, as well as significant inputs such as time, costs, and even changes in lifestyle (Fine, 1990:4). The price was seen as non-material and included aspects such as unrealistic role expectations, time consuming studies, exposure to inappropriate role models, non-competitive salaries, irregular hours, stress and anxiety. Price is thus viewed as input of time and sacrifices made by the nurse. A realistic marketing programme should therefore include all these price related matters.

Promotion refers to the manner in which the producer communicates with potential consumers (Fine, 1990:4). The promotion of the course was divided into advertisements which may be any paid form of providing information, personal selling including interpersonal contact, and public relations including exhibitions. Sales promotions such as incentives were not mentioned.

The place is seen as the institution where the product is made available (Fine, 1990:4). Respondents included the college, hospital and community institutions as the place, which required require clarification in the second Delphi round.

Market research should assess the need for the product, as well as the evaluation of the marketing programme, including feedback from the consumer (Fine, 1990:4). The panel members identified the assessment of the supply and demand of nurses, a general situational analysis and market development as the content of market research.

As far as the specific content of a marketing programme for the nursing college is concerned, the panel members mainly identified recruitment strategies like public appearances, recruitment pamphlets / information, press releases and general portrayal of a positive image. No suggestions regarding the market research, producer, product, price or consumers were made.

Phase two: Inclusion and impact of markeling actions

The results of the first Delphi round were structured and divided into three sections. Except for biographical information in section one, the marketing value of actions, indicating preferred inclusion of each action in the marketing strategy, was collected in section two and the third section dealt with the impact value of each marketing action. A seven point rating scale was used. A rating of five or higher

\begin{tabular}{|c|c|c|}
\hline \multicolumn{3}{|c|}{$\begin{array}{c}\text { Table } 1 \text { Distribution of inclusion and impact results of marketing } \\
\text { strategies and marketing agent }(\mathrm{N}=64)\end{array}$} \\
\hline Marketing action & Inclusion & Impact \\
\hline \multicolumn{3}{|l|}{ Marketing strategy } \\
\hline Recruitment & 5,578 & 5,922 \\
\hline Advertisement & 5,453 & 5,422 \\
\hline Publicity & 5,313 & 5,969 \\
\hline Professionalism & 5,453 & 6,078 \\
\hline \multicolumn{3}{|l|}{ Marketing agent } \\
\hline Nursing college & 5,953 & 5,922 \\
\hline Hospital & 5,953 & 6,281 \\
\hline Educational staff & 5,813 & 5,844 \\
\hline College/hospital team & 6,391 & 6,266 \\
\hline Nursing students & 5,857 & 5,906 \\
\hline All professional nurses & 6,141 & 5,797 \\
\hline
\end{tabular}

indicated a positive inclusion of marketing actions into the marketing programme or strategy of the nursing college. The impact value was also calculated to verify the importance and priority of certain marketing actions. Although the results of this questionnaire were analysed according to the various institutions, as well as the post level of the respondents, only sum totals will be given in this article.

This questionnaire was distributed to all the 77 panel members who responded to the first questionnaire. In this second round the sample realisation was $64(85,3 \%)$.

A total of 68 items were generated during the first Delphi round. When analysing the results it was clear that the respondents included almost all the items in the marketing strategy (mean ratings of five or higher).

Table 1 reflects the results of the marketing strategies to be employed, as well as the marketing agents. It is interesting to note that the nursing college and hospital were evenly rated as marketers, with the emphasis on the team effort between the two institutions. According to Britz (1989:15) marketing should be a team effort, but the success of a marketing programme is based on a structured team effort with a marketing committee and the various responsibilities assigned to specific committee members.

All professional nurses are seen as the most important agents in marketing the nursing profession. These results are supported by McKenna (1991) and Johnston (1991), who are of the opinion that marketing should be part of every person's job description in an organisation. The hospital's impact was seen as very important as being the place where the professional nurse should render quality nursing care. Professionalism displayed by all nurses is rated high in tenns of the impact.

The target groupratings are illustrated in Table 2. Note that the scholars were not rated as the primary target group - this was criticised later by the marketing consultant. The general public and influential community leaders received the highest rating and the teachers and school principals were seen as the priority target group in terms of impact. Kirby (1991:115) believes that scholars are important at the age where subject choices are made, but information packages do not have significant impact on their career choice later.

As far as marketing of the product is concerned, the highest rating was given to realistic information to counteract unrealistic expectations (see Table 2). The highest impact value was given to information regarding nursing as a profession. This is confirmed by Green (1987) who is of the opinion that scholars highly value a career which is classified as a profession. The product should always be marketed as valuable to the consumer and include an explanation of the value system upheld by that particular institution (Cushman, 1987; Porter, 1985).

McKenna (1991) and Johnston (1991) are both of the opinion that the quality of the product should be marketed as well as the credibility of the marketing agent. Lindeman (1987) supports the fact that the theoretical content of a course should be marketed with focus on the market value of the product.

The highest rating to price related marketing actions was attributed to the length or duration of the study and the highest impact area was seen as the anxiety students may experience in the clinical practice (see Table 2). Unsocial working hours received the lowest inclusion rating in this section.

Several promotional strategies were suggested, of which direct public relations or interpersonal contact received the highest inclusion rating (see Table 3). Highest impact rating in this section was given to the correct information to schools. The respondents show significant insight into the various promotional strategies and dealt fully with this area. Most of these strategies are supported by literature and research. A telephone information service is recommended by Jolma and Weller (1989). 
Table 2 Distribution of inclusion and impact results of the market, product and price $(\mathrm{N}=64)$

\begin{tabular}{|lcc|}
\hline Marketing action & Inclusion & Impact \\
\hline Market & & \\
Scholars & 5,766 & 4,828 \\
Community leaders & 6,266 & 6,359 \\
Parents & 5,078 & 5,875 \\
Educational leaders & 5,578 & 6,391 \\
General public & 6,313 & 6,048 \\
Teachers and principals & 5,203 & 6,734 \\
\hline Product & & \\
Advantages / disadvantages nursing & 6,188 & 5,766 \\
Professional/personal growth & 5,938 & 6,078 \\
Nursing profession & 5,453 & 6,563 \\
Conditions of service & 6,344 & 6,094 \\
Course content / theory & 5,672 & 5,734 \\
Job satisfaction & 6,000 & 6,328 \\
Realistic information & 6,484 & 5,625 \\
Valuable training/education & 6,109 & 6,297 \\
\hline Price & & \\
Role expectations & 5,078 & 5,625 \\
Non competitive salary & 5,078 & 5,500 \\
Anxiety in nursing units & 5,344 & 6,000 \\
Duration of study & 6,297 & 5,828 \\
Unsocial hours & 4,344 & 5,766 \\
\hline
\end{tabular}

\begin{tabular}{|lcc|}
\hline \multicolumn{3}{|c|}{$\begin{array}{c}\text { Table } 3 \text { Distribution of inclusion and impact results } \\
\text { of the promotion strategies }(\mathrm{N}=64)\end{array}$} \\
\hline Marketing action & Inclusion & Impact \\
\hline Promotion strategies & 5,609 & 5,422 \\
Advertisements & 5,672 & 5,922 \\
Opinion survey & 5,328 & 6,188 \\
Recruitment pamphlets & 5,969 & 5,797 \\
Television programmes & 5,578 & 5,922 \\
Direct recruitment programmes & 6,250 & 6,078 \\
Interpersonal contact & 6,109 & 6,297 \\
Information at schools & 5,578 & 5,922 \\
Recruitment / open days & 5,563 & 5,453 \\
Exhibitions. & 5,359 & 5,406 \\
Holiday work & 5,703 & 5,969 \\
Public appearance / relations & 5,453 & 5,969 \\
Mother / daughter days & 5,266 & 5,095 \\
\hline Telephone information service & & \\
\hline
\end{tabular}

Table 4 Distribution of inclusion and impact results of the marketing place, marketing research and marketing educational programme $(\mathrm{N}=64)$

\begin{tabular}{|lcc|}
\hline Marketing action & Inclusion & Impact \\
\hline Place & & \\
Community institutions & 5,172 & 5,078 \\
Nursing college & 6,266 & 5,109 \\
Hospitals & 5,953 & 6,281 \\
\hline Market research & & \\
Assessment in clinics & 5,547 & 5,766 \\
Supply / demand analysis & 6,313 & 5,922 \\
General situational analysis & 5,734 & 5,797 \\
\hline Marketing educational programme & & \\
Strategy & 6,031 & 5,766 \\
Public appearance & 6,313 & 6,234 \\
Recruitment techniques & 6,313 & 6,234 \\
Professional image/ appearance & 6,344 & 6,563 \\
Communication in recruitment & 6,109 & 6,234 \\
Press releases / media information & 6,016 & 5,750 \\
\hline
\end{tabular}

The nursing college and the hospitals seem to be the most important marketing places, with the highest impact rating given to the hospitals, as reflected in Table 4 . In terms of the market research, a supply and demand analysis of the nursing profession received the highest inclusion rating. This is very costly and has been carried out by the South African Nursing Council and Association in 1990. Most of the authors emphasize the importance of the most realistic place where marketing will receive the necessary attention and information is most accessible to the consumer

The respondents were very much in favour of a marketing educational programme, with the contents included as illustrated in Table 4. The highest impact rating was attributed to professional image and appearance. It therefore seems as if the potential marketers have a need for inservice training in public speaking, as well as in all the other aspects of marketing. Warwick (1987) and Thompson (1987) agree that those marketing agents in the profession who are exposed to public speaking and appearances, should receive the necessary education in this regard.

Phase three: Guidelines for a marketing strategy for a nursing college

The results obtained in the second phase were verified with some of the panel members as well as a marketing consultant. The marketing consultant confirmed that marketing is an interactional process of planned activities to communicate with potential consumers. Panel members agreed that a marketing committee, consisting of college and hospital staff, should be established. The nursing college remains, however, the main marketing agent and producer of the nursing course but both nursing college and hospital staff have co-responsibility in producing professional nurses of a high standard. A marketing strategy for the nursing college was designed based on the results of this study and the literature review.

Figure 1 illustrates the content of the marketing strategy, consisting of a general situational analysis, market analysis, mission formulation, market segment, marketing strategy mix and a marketing audit.

\section{General situational analysis}

The execution of a situational analysis provides information regarding the internal and external environment of the nursing college and health care institutions. An internal analysis of the nursing college and health care institutions is performed in terms of staff composition, student population and characteristics, infrastructures, management systems and styles, value systems, course / curriculum content, as well as expertise and interest in marketing. Marketing therefore should form part of the general strategic analysis. The external environmental analysis includes data collection of all the schools, 


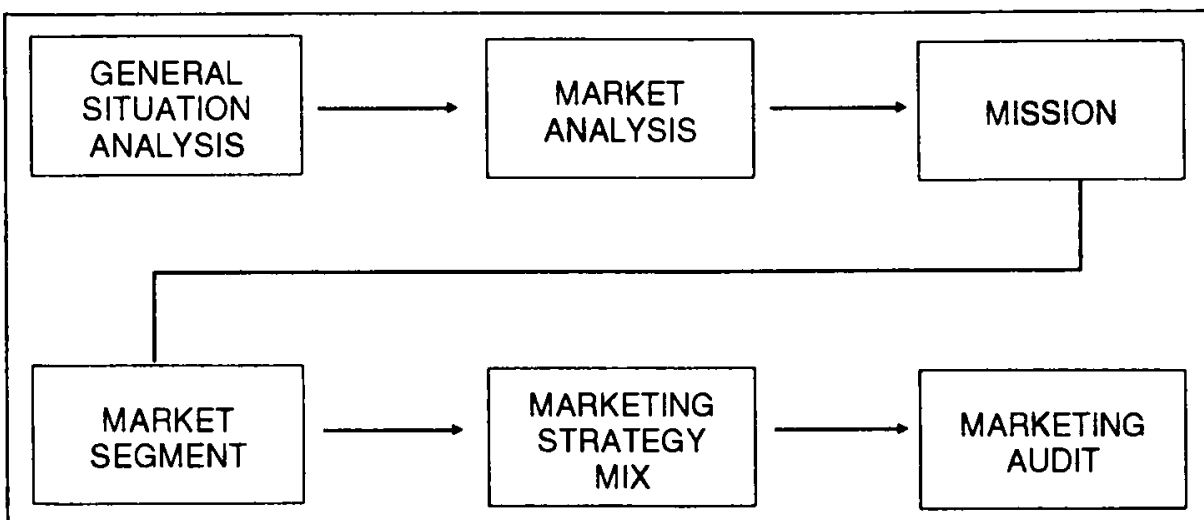

Figure 1 Marketing strategy for a nursing college

community institutions and leaders, government and private sectors, health related legal framework, the existing health plan, general public, health care systems and needs, media dynamics and the competitive market. A strategic analysis is performed to determine the strengths, weaknesses, opportunities and threats focused on marketing.

\section{Market analysis}

It is important to study the present and potential consumers to determine their needs and to divide the market in segments for the study of homogenous groups. An analysis of the competitive market seen as other competitive careers as well as other nursing colleges should receive attention. Only when the producer knows how the consumer functions and what his values are, will the producer be able to plan a marketing strategy.

Data collected in the market analysis should provide the basis for tactical planning to counteract the existing competition in the market and to increase the value of the product. The market analysis should focus on the following:

- piesent and potential consumers: scholars, influential community leaders, school teachers/career counsellors, health care consumers, etc.;

- other competitive careers;

- other nursing colleges operating in the same market: type of courses offered, value systems, quality of product, etc.

\section{Mission statement}

A mission statement is formulated to accommodate the marketing strategy of the nursing college. The mission statement (marketing strategy) of the nursing college should:-

- strive towards effective communication with the consumer:

- strive towards offering a high quality product (nursing course);

- strive towards a significant contribution to health care by appropriately educated professional nurses;

- positively influence the image of nursing.

\section{Market segment}

Market segment refers to the division of the market to enable the design of a marketing strategy for a specific segment of the market (Fine, 1990:82). The market segment for the nursing college's marketing strategy is the following:

- scholars as the main target group;

- influential community leaders;

- school teachers / career counsellors and principals.

The general public always remain an important target group but it is not realistic to focus on them in a marketing strategy

\section{Marketing strategy mix}

The marketing strategy mix is calegorised as follows: the producer or marketing agent, the consumer, product, price, promotion, place and market research. The marketing strategy can only be planned when information of previous strategic steps taken is available. It is important to identify the person responsible for marketing (marketer) and appoint a marketing committee to present a co-ordinated programme. Definite marketing responsibilities should be assigned to the marketing agent and committee members. As the consumer is identified as the scholar, most actions should be focused on the inclusion of the scholar in the programme. The marketing strategy mix of the nursing college should include at least the following:

a) product

- quality nursing course(s);

- realistic information regarding nursing:

- nursing as a profession: status value;

- advantages and disadv antages of nursing as a career/profession;
- conditions of service in the nursing profession

- job satisfaction experienced as a professional nurse;

- personal and professional growth in following a nursing career;

- valuable / quality education.

b) Price

- duration of the study;

- anxiety implications in nursing units;

- role expectations;

- non-competitive salary;

- unsocial hours

c) Promotion strategies

- direct interpersonal contact with target groups;

- updated information to schools;

- opinion surveys amongst scholars;

- advertisements, pamphlets, exhibitions and media programmes;

- open days at college and clinical areas;

- holiday work by scholars;

- telephone information service;

- professional public appearances and speaking by nurse leaders;

- mother/daughter days.

d) Place

- nursing college and clinical facilities

- community institutions.

\section{e) Market research}

The general situational analysis, as described, in terms of the internal and external environmental analysis. competitive market and strategic marketing planning.

\section{Marketing audit}

The marketing audit refers to the continuous evaluation of the marketing strategy, as each step is implemented. The feasibility of the marketing strategy in terms of input and output (success) should be determined.

\section{CONCLUSION AND RECOMMENDATIONS}

Every nursing college requires a well planned marketing strategy, implemented to meet the 
needs of that nursing college and the community at large. But marketing can be very costly - therefore the marketing strategy should be focused and feasible. In this study the content of a marketing strategy for a nursing college was explored and described. The professional nurse as a potential marketing agent does not have the appropriate knowledge regarding marketing. Some recommendations are highlighted.

\section{a) Nursing college practice and research}

The implementation and evaluation of a nursing college marketing strategy is recommended. Research on the effectiveness of a marketing plan should be conducted, focusing on specific target groups to identify the significance of impact. It is recommended also that a marketing model for nursing colleges is developed. Intensive market research is recommended to determine the values and needs of the consumer, as well as the benefits and values of the nursing profession. More research on the image of the nursing profession is required.

\section{b) Nursing education}

The planning, implementation and evaluation of a professional development programme related to marketing as a responsibility of all nurses as potential marketers, is recommended. Marketing models, strategies, skills and responsibilities should be included in the curricula of all nursing education and nursing administration programmes.

Marketing should always be part of an institution's strategic plan.

\section{ACKNOWLEDGMENTS}

The input of all the panel members is hereby acknowledged, as well as financial support by the Transvaal Provincial Administration and the South African Nursing Association. This article is partially based on a master study.

\section{REFERENCES}

Baird, F (1991): Marketing the nursing profession Nursing RSA Verpleging, 6(5): 21-23.

Britz, RJ (1989): Die taak van die Senior Adjunk-Prinsipaal by 'n Tegniese Kollege. Johannesburg: RAU (M.Ed.-skripsie).

Cushman, M (1987): In search of excellence. American Journal of Nursing, 87(12):December 1987.

De Jager, JI (1990): Skakelwerk en reklame - 'n toekomsp erspektief. (Ongepubliseerde referaat gelewer by Direktoraat Skakeldienste TPA).

Du Toit, CM (1992): Involving staff in development activities: a narketing framework. South African Journal of Health Education. 6(1):83-90.

Esterhulzen, JM (1989): 'n Ondersteuningstelsel vir studentverpleegkundiges: in verpleegdinamiese perspektief. Johannesburg: RAU (M.Cur.-verhandeling).

Fine SH (1990): Social marketing. Promoting the causes of public and non-profit agencies. New Jersey: Allyn \& Bacon.

Green, K (1987): What the Frenchmen tell us. American Journal of Nursing, 87(12): December 1987.

Jolma, DJ \& Weller, DE (1989): An evaluation of nurse recruitment methods. Journal of Nursing Administration, 19(4): April 1989.

July, FM (1988): Recruitment and retention of black students in Baccalaureate nursing programs. An application of the marketing process. University Microfilms intemational July 1988

Johnston, M(1991): Customer service and physical distribution: dimensions and some strategies for achieving them. International Journal of Physical Distribution \& Logistics Management, 21(5): May 1991.

Kirby, LA (1991): 'n Werwingstrategie vir studentverpleegkundiges. Johannesburg: RAU (M.Cur. verhandeling).

Lindeman, CA (1975): Delphi survey of priorities in clinical research. Nursing Research 24(b) Nov/Dec 1975
Massie, JL (1979): Essentials of management; 3rd edition. New Jersey: Prentice Hall.

McKenna, R (1991): Marketing iis everything. Harvard Business Review, January/February 1991.

Muller, ME (1991): Die vraag na en aanbod van verpleegkundiges in Suid-Afrika. Curationis. 14(1): Maart 1991 .

Porter, ME (1985): Competitive advantage. Creating and substaining superior performance. New York: Free Press.

Schulz, R \& Johnson, AC (1990): Management of hospitals and health services: strategic issues and performance; 3 rd edition. St Louis: Mosby.

Selder, FE \& Wassem, RA (1990): Nursing and marketing collaborative teaching. Nurse Education, 15(4): 23-27.

Stanton, WJ (1975): Fundamentals of marketing New York: McGraw Hill.

Strasen, L (1987): Key business skills for nurse managers. Philadelphia: Lippincott.

Thompson, B (1987): In search of excellence. American Journal of Nursing. 87(12):December 1987.

Warwick, M (1987): Strategies for change. Ameriean Journal of Nursing, $87(12)$ December 1987.

Woolf, J (1987): Who'd be a nursing student? Nursing Times, 83(31).

M Pryde RN.
M.Cur. Student RAU
RAND AFRIKAANS UNIVERSITY
M Muller Ph. D. R.N.
Professor
Dept of Nursing Science
RAND AFRIKAANS UNIVERSITY

